\title{
Harry Oppenheimer Fellowship Awards, 2016
}

AUTHOR:

John Butler-Adam ${ }^{1}$

\section{AFFILIATION:}

${ }^{1}$ Academy of Science of

South Africa, Pretoria,

South Africa

CORRESPONDENCE TO:

John Butler-Adam

EMAIL:

j.butleradam@gmail.com

\section{POSTAL ADDRESS:}

Academy of Science of

South Africa, P0 Box 72135 ,

Lynnwood Ridge 0040, Pretoria, South Africa

\section{KEYWORDS:}

fungal genomics; ascomycetes; tree pathogens; Nelson Mandela; biography; Romantic hero; tragic hero

\section{HOW TO CITE:}

Butler-Adam J. Harry

Oppenheimer Fellowship

Awards, 2016. S Afr J Sci.

2016;112(7/8), Art. \#a0164,

2 pages. http://dx.doi.

org/10.17159/sajs.2016/a0164
The Harry Oppenheimer Fellowship Awards were initiated in 2001 to commemorate the Oppenheimer Memorial Trust's founder and all he stood for. Especially important were his efforts to support human and intellectual development, advance scholarship and encourage innovative ideas. The Trust has a long tradition of investing in education and many beneficiaries have gone on to make important contributions to South African public life. The fellowships build on this tradition and, with a monetary value of R1.5 million, rank as the Trust's premier annual awards. These are special investments to encourage excellence in scholarship in all disciplines and in all its forms. The awards serve to acknowledge cutting-edge, internationally significant work that has particular application to the advancement of knowledge, teaching, research and development in South Africa.

The 2016 award was unusual in that two awards were made instead of a single recipient being selected, as in most years. One award was made to Professor Brenda Wingfield of the University of Pretoria and another to Professor Xolela Mangcu of the University of Cape Town.

\section{Brenda Wingfield}

Brenda Wingfield is a professor of genetics at the University of Pretoria. She holds the South African Research Chairs Initiative (SARChl) Chair in Fungal Genomics, and is internationally recognised as a world leader in her field. She is a past chair of the National Science and Technology Forum, and currently serves in leadership roles in national and international structures. She is vice-president of the Academy of Science of South Africa; convener of the National Research Foundation (NRF) rating specialist committee for microbiology and plant pathology; secretary-general of the International Society of Plant Pathology; and a project leader at the Centre of Excellence in Tree Health Biotechnology (run by the Department of Science and Technology together with the NRF). She is Deputy Dean of Research in the University's Faculty of Natural and Agricultural Sciences.

Brenda Wingfield was born in Zambia, completed her schooling in Zimbabwe, and calls South Africa her home. She obtained her BSc and BSc Hons degrees at the Universities of Natal and Cape Town respectively, a Master's in biochemistry from the University of Minnesota, and her Ph.D at the University of Stellenbosch. Prof. Wingfield and her husband Prof. Mike Wingfield took up posts at the University of Pretoria in the late 1990s, and together with other experts established the Forestry and Agricultural Biotechnology Institute.

Brenda Wingfield's contributions to science have been widely recognised. Over the years she has received the following awards:

- Women in Water, Sanitation, and Forestry Research Award: Department of Water Affairs and Forestry (2007)

- Distinguished Women in Science Award: Department of Science and Technology (2008)

- Women in Science (Southern Region) Award: African Union (2009)

- BHP Billiton Outstanding Contribution to SET Research Capacity Building: National Science and Technology Forum (2014)

- Christiaan Hendrik Persoon Medal for Outstanding Achievement in Plant Pathology: Southern African Society for Plant Pathology (2015).

In 2013, Prof. Wingfield received an A-rating from the NRF. Her research over the past 20 years has focused on the global movement and evolution of fungal pathogens, particularly those which cause tree disease. She was instrumental in developing the first DNA-based phylogenes for a number of important tree pathogens. She also helped to develop molecular tools to study the population diversity, origins and movements of many tree pathogens around the world. She sequenced the first fungal genome in Africa.

Prof. Wingfield's current project aims at achieving better understanding and characterisation of the mating type locus in a group of fungi known as ascomycetes. The vast majority of tree pathogens are fungal and belong to this group. Genes are central to sexual reproduction in fungi, as elsewhere, and recombination between mating genomes is one of the driving forces in their evolution and genetic change. Studies such as Prof. Wingfield's are important for managing plant and tree pathogens because of the 'arms race' between pathogens and their hosts. The capacity of a pathogen to adapt and change in response to the defences of its host defines the pathogen's ability to survive. The international community of mycologists has embarked on 'The 1000 Fungal Genomes Project', and Prof. Wingfield with her collaborators and graduate and postdoctoral students at the University of Pretoria are enthusiastic members of this initiative. The Harry Oppenheimer Fellowship Award will make the project possible on an ambitious scale.

\section{Xolela Mangcu}

Xolela Mangcu is a professor in the Department of Sociology at the University of Cape Town. He has held fellowships at the prestigious Brookings Institution, the W.E.B. Du Bois Institute, and the Hutchins Center for African and African-American Studies at Harvard University. He is a leading columnist and political commentator, and has published nine books including Biko: A Biography, for which he won the University of Cape Town book award.

Xolela Mangcu was born to a family of educators in Ginsberg Township in King William's Town, which was also the hometown of Steve Biko (his childhood political inspiration). Prof. Mangcu studied at local schools, and later attended the University of the Witwatersrand in 1984 under a quota system for then designated white universities. 
He soon became a prominent member of the Black Consciousness student movement. After completing a degree in law and sociology, he obtained a master's degree in Development Planning (Wits, 1988) and soon after was admitted as a Fellow in the Special Program in Urban and Regional Studies at Massachusetts Institute of Technology. Prof. Mangcu completed his PhD in city and regional planning at Cornell University in 1997. Other fellowships followed - at the Rockefeller Foundation and Harvard's John F. Kennedy School of Government - before he returned to South Africa in 1999. He launched the Steve Biko Foundation in 2000, in partnership with the Biko family and local youth. From 2006 to 2011 he divided his time between the University of the Witwatersrand and the University of Johannesburg, and he joined the University of Cape Town in 2012.

Prof. Mangcu will use the Harry Oppenheimer Award to write a new and highly contextualised biography of Nelson Mandela. One of the qualities Mangcu greatly admired in Mandela was that he was embraced by the great man, even though he was essentially Mandela's critic. The idea of someone being Mandela's critic was jarring in a world where Mandela has been treated as a god-like figure. Prof. Mangcu believes that because of this 'hero-worship', many of Mandela's biographers have abstracted Mandela from the political debates and controversies that have animated the world of black South Africans since their earliest encounters with colonialism. The result is an abstracted morality tale instead of engagement with Mandela as a contested figure, both within the African National Congress and various political movements. (The latter include the All-Africa Convention, the New Unity Movement, the Pan Africanist Congress and the Black Consciousness movement.)

Prof. Mangcu thus intends to address broader questions of history. Among his aims are to examine the activities of organisations such as the South African Native Association (Imbumba) in Tembuland; the political and electoral campaigns for African representation in the Cape Parliament; the rise of the African Christian church; and the political and intellectual writing of African greats such as Tiyo Soga, Walter Rubusana, D.D.T. Jabavu, John Tengo Jabavu, David Malasi, Richard Kawa, Meshack, James Pelem and many others.

Writing the new book will involve conducting empirical research in South Africa and spending time at Harvard to write up the findings and engage with leading scholars. Prof. Mangcu has titled his work Paradoxical Mandela: Romantic Hero, Tragic Hero to highlight the difference between the predominantly Romantic representation of Mandela as an individual hero of the liberation struggle and the Classic idea of tragedy as communal action. Whereas liberal Romantic tragedy focuses on what happens to the hero, Classic tragedy focuses on what happens through the hero. (This formulation was proposed by Raymond Williams.) Thus, in Classic Greek tragedy, tragic action continues even after the hero has died or stepped off the stage. The action continues through the chorus, the audience's response to the tragedy and the energies that are released in the action. The hero, chorus and audience keep returning to the scene despite its dangers, driven by the desire to give to the world what Steve Biko called 'a more human face'. This is another way to describe tragic hope as the spur for human action. These insights are profound for present-day South Africa, and I look forward to the completion of this important task.

Previous recipients of the Oppenheimer Fellowship Award are:

2014: Helen Rees, Obstetrics and Gynaecology, Wits Reproductive Health \& HIV Institute, University of the Witwatersrand

2013: Keertan Dheda, Respiratory Medicine, University of Cape Town

2012: Robin Crewe, Zoology and Entomology, University of Pretoria

2011: Leslie Underhill, Zoology, University of Cape Town

2010: Duncan Mitchell, Physiology, University of the Witwatersrand

2009: Jill Farrant, Molecular Physiology, University of Cape Town

2008: Philippe-Joseph Salazar, Rhetoric Studies, University of Cape Town

2007: Jeff Guy, History, University of KwaZulu-Natal, Winston Hide, Bioinformatics and Cancer Research, University of the Western Cape

2006: Paul Cilliers, Philosophy and Ethics, University of Stellenbosch

2005: Norman Owen-Smith, Environmental Sciences, University of the Witwatersrand

2004: Igor Barashenkov, Mathematics and Applied Mathematics, University of Cape Town Frank Brombacher, Immunology and Infectious Diseases, University of Cape Town

2002: Jan-Hendrik Hofmeyr, Biochemistry, University of Stellenbosch

2001: David Glasser, Chemical Engineering, University of the Witwatersrand 